https://dx.doi.org/10.4314/jpb.v17i2.10

Vol. 17 no. 2, pp. 164-173 (September 2020)

http://ajol.info/index.php/jpb
Journal of
PHARMACY AND BIORESOURCES

\title{
Ameliorative and fecundity potentials of aqueous extract of Azanza garckeana (T. Hoffm) fruit pulp in formalin-induced toxicity on male albino mice
}

\author{
Bukata B. BUKAR*, Naomi E. TSOKWA and Omolola D.G. ORSHI \\ Department of Pharmacology and Toxicology, University of Jos, Jos. Nigeria.
}

Received 14 ${ }^{\text {th }}$ June 2020; Accepted $10^{\text {th }}$ August 2020

\begin{abstract}
The study investigated the ameliorative and fecundity potentials of Azanza garckeana on formalin-induced toxicity in mice testes. Male albino mice were divided into eight groups of five mice each. Group I was administered normal saline ( $1 \mathrm{ml} / \mathrm{kg}$ per oral); Group II received formalin $(10 \mathrm{mg} / \mathrm{kg}$ ) alone; Groups III, IV and V received formalin (10 $\mathrm{mg} / \mathrm{kg}$ IP) plus extract (orally) at 125,250 and $500 \mathrm{mg} / \mathrm{kg}$ respectively for 40 days; Groups VI, VII and VIII received extract alone at 125,250 and $500 \mathrm{mg} / \mathrm{kg}$ respectively. Gonadotropin assays and sperm analysis were carried out using standard methods. Animals in groups III to VIII showed significant body weight increase compared to baseline value ( $\mathrm{p}<0.05$ ) from day 20 to 40 . Co-administration of the extract at 250 and $500 \mathrm{mg} / \mathrm{kg}$ with formalin caused a significant increase in weight of the epididymis compared to control ( $<<0.05$ ). Extract at 125 and $500 \mathrm{mg} / \mathrm{kg}$ induced significant increase in LH, FSH and testosterone compared to control ( $p<0.05)$. Extract alone at 250 and $500 \mathrm{mg} / \mathrm{kg}$ caused significant increase in FSH compared with control $(\mathrm{p}<0.05)$. Extract at $250 \mathrm{mg} / \mathrm{kg}$ demonstrated highest fecundity potential of 8.49. These results imply that Azanza garckeana possesses ameliorative and pro-fertility properties.
\end{abstract}

Keywords: Azanza garckeana; Gonadotropins; Aphrodisia; Fecundity; Gonadosomatic index; Sperm Motility

\section{INTRODUCTION}

Azanza garckeana is a deciduous shrub that grows to a height of 3-15 m. It grows naturally in Tropical regions of Africa especially at $1700 \mathrm{~m}$ above sea level with total annual rainfall of between 250 and $1270 \mathrm{~mm}$ [1]. In Nigeria, it grows mainly in a town called Tula in Kaltungo Local Government Area of Gombe State, North-East region. It is also found in other African countries such as South Africa, Mozambique, Botswana, Zimbabwe, Tanzania, DR Congo, Kenya, Malawi and Namibia. It is known by different common and local names that include "silky kola", "snot apple", "chewing gum" and in the local Hausa language, "Goron Tula" ("Tula" being the town it grows naturally in Nigeria while "goro" means kola). In Nigeria, particularly around the areas among the communities where it grows naturally Azanza garckeana has been associated with many socio-medicinal uses in their traditional settings. It is traditionally used for the treatment of various ailments that include chest pain, cough, stomachache, menstrual disorder and sexuallytransmitted diseases such as gonorrhea and

*Correspondence. E-mail: bukata33@yahoo.com Tel: +234-8036183979

ISSN 0189-8442

(cc) BY-NC 2020. Published by Faculty of Pharmaceutical Sciences, University of Jos, Nigeria. Under Creative Commons Attribution-NonCommercial 4.0 International License. https://creativecommons.org/licenses/by-nc/4.0/ 
syphilis. It is also used traditionally to enhance libido as its consumption is traditionally claimed to enhance development of a strong desire for sexual intercourse in both males and females alike, suggesting its possible aphrodisiac property. Azanza garckeana has been reported to possess antibacterial and antifungal activities [2-5], anti-hyperglycemic effect [6], antioxidant and cytotoxicity activity $[5,7]$ and antimalarial property [8]. Some of these pharmacological properties have been attributed to some of the phytochemicals such as tannins, flavonoids, saponins, alkaloids and xanthones that are found in it [3,9-11].

It has also been reported to have high quality pectin of good industrial application especially in food and pharmaceutical industries [12]. Azanza garckeana has also been found to improve growth rate when included in a diet or feed at above $20 \%$ in fish [13]. Curiously, Azanza garckeana is reported to have significant influence on fecundity and potential pro-fertility property in fish [14].

Given that male reproductive health has generally received only a little attention over the years $[15,16]$, the aim of the present study was to investigate the ameliorative and fecundity potentials of Azanza garckeana on formalin-induced toxicity in mice testes. This is premised on the earlier traditional claims that Azanza garckeana enhances sexual appeal and desire for sexual intercourse which are both characteristics of aphrodisia and fecundity potentials.

\section{EXPERIMENTAL}

Laboratory animals. Forty adult male albino mice weighing between 24 and $37 \mathrm{~g}$ were purchased from the Animal Experimental Unit of the University of Jos. They were approved and certified for the experiment by the Committee on use of experimental animals' protocol of the Department of Pharmacology and Toxicology, University of Jos (Certificate Number F17-00379). The mice were handled under ethical conditions for the use and care of laboratory animals [17]. The animals were fed with standard solid nutritional pellets and water ad libitum until the commencement of the experiment.

Preparation of extract. Azanza garckeana pulps were purchased from a reputable dealer in a local market in Tula town of Kaltungo local government area, Gombe state of North East Nigeria in the month of November September 2018. The pulps were reauthenticated by a taxonomist, Mr. Christopher John of the Federal College of Forestry, Jos, Plateau State and an herbarium voucher specimen (number FHJ/260) was prepared. The pulps were removed, washed, and carefully crushed in small pieces to enhance drying. They were then dried under shade in the laboratory. Thereafter, they were grounded to a finer powder using mortar and pestle, and extracted according to the method described by Adegboye et al [18. The powdered fruit pulp (600 g) was extracted continuously with distilled water in a Soxhlet extractor for 25 hours at $55{ }^{\circ} \mathrm{C}$. The extract was evaporated to dryness in a vacuum evaporator at $50{ }^{0} \mathrm{C}$ until a constant yield of $348.2 \mathrm{~g}$ (representing $58.03 \%$ ) following repeated weighing was obtained. The extract which was brownish in color and sticky in consistency was reconstituted in normal saline for the purpose of the experiment.

Phytochemical analysis. The phytochemical analysis was carried out using various methods for each constituent that include alkaloid, saponin and carbohydrates (19), tannins (20), anthraquinones (21), steroids (22), and terpenes (23)

Treatment of animals. The forty male albino mice were randomly divided into eight groups of five mice each. The first group (I) was the control group and were administered normal saline $(1 \mathrm{ml} / \mathrm{kg})$ by the oral route every morning daily for 40 days. Animals in group II received formalin by the IP route $(10 \mathrm{mg} / \mathrm{kg})$ while groups III, IV and V received in addition 
to formalin, the extract at doses of $125 ; 250$ and $500 \mathrm{mg} / \mathrm{kg}$ respectively by the oral route. Mice in groups VI, VII and VIII were administered the extract alone at doses of 125; 250 and 500 $\mathrm{mg} / \mathrm{kg}$ by the oral route for same duration of 40 days. The weights of each mice in the respective groups were determined periodically at 10-day intervals until the end of the 40 days treatment.

\section{Determination of serum gonadotropin levels} and testicular weights. The micro well enzyme-linked immunoassay (ELISA) method which is based on competitive binding of the gonadotropins on immobilized specific antibody as described by Braide [24] and; Gan and Patel [25] was used. In the procedure, the animals were anesthetized using chloroform and blood samples obtained through cardiac puncture 24 hours after the last dose. The blood samples from each mouse were collected in a non-heparinized sample bottle and allowed to stand for 3 hours in iced water. Thereafter, it was centrifuged at $3000 \mathrm{rpm}$ for 10 minutes to separate the serum from clots. The serum was collected and stored at $-20^{\circ} \mathrm{C}$ until needed for the experiments. . Bioassay using the micro well ELISA method was carried out for the gonadotropins that include luteinizing hormone $(\mathrm{LH})$, follicle stimulating hormone (FSH) and testosterone.

Sperm concentration/motility assay. The method reported by Bavister and Andrews [26] was adopted with modifications. Following the last dose of the daily administrations of the extract and normal saline, the mice were allowed to rest for 24 hours. Thereafter, the distal caudal epididymis was dissected and placed in an equilibrated $2 \mathrm{ml}$ Tyrode's solution in a petri dish. A hypodermic needle was used to release the sperm cells from the caudal epididymis into the medium. The sperm cells were allowed to swim out into the medium for about 4 minutes. Sperm concentrations were then determined by physical count under the electronic microscope (Olympus, model c47, Japan) at a magnification of $\mathrm{x} 400$. Thereafter, a culture was added to the culture for sperm motility assay. The rapid motility was determined after 4 hours as the cut-off time.

Determination of testicular profile, epididymal weights and GSI. The right and left testes for each mouse were carefully removed and their lengths and weight measured separately for each group. In similar manner, the epididymis was isolated and weighed for each animal. The data generated was used to calculate the GSI.

Analysis of data. Data were collected and expressed as Mean \pm SEM. They were analyzed statistically using student's t-test and the two-way ANOVA on the IBM SPSS 23 Statistical Software Program. The level of statistical significance was placed at $\mathrm{p}=0.05$, using the Bonferroni Post Hoc test.

\section{RESULTS}

Phytochemical composition. Result for the phytochemical screening of the aqueous extract of Azanza garckeana is presented on table 1. The result reveals the presence of flavonoids in large quantity, followed with alkaloids and cardiac glycosides. Steroids and tannins were present in much lower quantity while saponins, terpenes and anthraquinones were absent.

\section{Effect of Azanza garckeana on body weight} of mice. The results of the effect of daily of Azanza garckeana alone and in formalininduced toxicity are presented on table 2 . The results indicate that formalin significantly decreased body weight compared to control group ( $\mathrm{p}<0.05)$, but not so when compared with the baseline value $(\mathrm{p}>0.05)$. Concurrent administration of formalin with the extract at the doses of 250 and $500 \mathrm{mg} / \mathrm{kg}$ from 20 to 40 days induced significant body weight increased compared to baseline value ( $\mathrm{p}<0.05)$. Similarly, the extract alone at all the doses used caused significant body weight increase from day 20 to 40 compared with 
baseline $(p<0.05)$. Generally, formalin alone caused body weight decrease at the end of day 40 while the extract caused increase compared with the baseline.

Testicular profile, epididymal weights and GSI of treated mice. The results as presented on table 3 showed that co-administration of the extract of Azanza garckeana at 250 and 500 $\mathrm{mg} / \mathrm{kg}$ with formalin caused a significant increase in weight of the epididymis compared to control $(p<0.05)$. However, both formalin and the extract either alone or in combination, caused inconsistent effect on the weight of testes, which were non-significant compared with control $(p>0.05)$. Results of the gonadosomatic profiles of control and treated mice are shown on table 4 . The extract of Azanza garckeana alone at all the doses used caused non-significant increase in the GSI of treated animals compared with control group $(\mathrm{p}<0.05)$. However, animals in the group that received formalin alone had significant increase in GSI compared to control ( $\mathrm{p}<0.05)$.

Effect of Azanza garckeana on gonadotropins. The results of the effect of the extract on gonadotropins are presented on table 5 . The results indicated that the extract alone at doses of 125 and $500 \mathrm{mg} / \mathrm{kg}$ induced significant increase in LH compared to control (group 1) and formalin alone (group 2) (p < 0.05). In a similar manner, the extract alone at doses of 250 and $500 \mathrm{mg} / \mathrm{kg}$ caused significant increase in FSH compared with the control and the group that received formalin alone $(\mathrm{p}<$ 0.05). Again, the extract alone at all doses caused significant increase in testosterone levels compared with the group that received formalin alone $(p<0.05)$. On the other hand, administration of formalin alone induced significant decrease in FSH and testosterone levels compared with the control $(\mathrm{p}<0.05)$
Effect of Azanza garckeana on sperm concentration and progressive motility

$i$. Effect on sperm concentration. The effects of the aqueous extract of Azanza garckeana on sperm concentrations are shown on figure 1 . The extract alone at doses of 250 and 500 $\mathrm{mg} / \mathrm{kg}$ caused significant increase on sperm concentrations compared to both the control and formalin alone-treated groups ( $\mathrm{p}<0.05)$. The extract at the dose of $125 \mathrm{mg} / \mathrm{kg}$ did not demonstrate any significant ameliorative effect in sperm concentration on formalin-induced toxicity $(\mathrm{p}>0.05)$. However, there was an observed ameliorative effect of the extract at the doses of 250 and $500 \mathrm{mg} / \mathrm{kg}$ of the extract by way of significant increase in sperm concentrations on formalin-induced toxicity ( $p$ $<0.05)$.

ii. Effect on progressive motility. The effects of the aqueous extract of Azanza garckeana on some sperm rapid progressive motility are shown on figure 2 . The extract alone at doses of 250 and $500 \mathrm{mg} / \mathrm{kg}$ caused significant increase on sperm cell motility compared to both the control and formalin alone-treated groups $(p<0.05)$. The extract at the dose of $125 \mathrm{mg} / \mathrm{kg}$ did not demonstrate any significant ameliorative effect on motility on formalininduced toxicity $(\mathrm{p}>0.05)$. However, there was an observed ameliorative effect of the extract at the doses of 250 and $500 \mathrm{mg} / \mathrm{kg}$ of the extract by way of significant increase in motility on formalin-induced toxicity ( $p$ < 0.05).

Determination of fecundity potentials. The results for the fecundity profiles are shown on Figure 3. Animals in the control group exhibited the highest fecundity potentials followed by the group that received the extract alone at $250 \mathrm{mg} / \mathrm{kg}$. The group with the least reproductive profile was the one that received formalin alone. The fecundity potential is testosterone production per unit of GSI which is expressed as:

Fecundity Potential $=\frac{\text { Amount of Testosterone }(\mathrm{ng} / \mathrm{dL})}{\mathrm{GSI}}$ 
Effect of gonadosomatic index with fecundity potential. The results for the comparative values of GSI with those of the Fecundity Potential are shown on figure 4. Animals that were administered formalin 10 $\mathrm{mg} / \mathrm{kg}$ alone (group 2) had the highest GSI of 1.53 , but curiously they also had the lowest reproductive potential of 2.81 as compared to other groups. The extract of Azanza garckeana alone at a dose of $250 \mathrm{mg} / \mathrm{kg}$ demonstrated the highest reproductive potential of 8.49 , but this value was lower than that of the control with 9.44 .

Table 1: Phytochemical composition of aqueous extract of Azanza garckeana fruit pulp

\begin{tabular}{|c|c|}
\hline Constituents & Composition \\
\hline Alkaloids & ++ \\
\hline Tannins & + \\
\hline Flavonoids & +++ \\
\hline Steroids & + \\
\hline Saponins & - \\
\hline Carbohydrates & +++ \\
\hline Cardiac glycosides & ++ \\
\hline Terpenes & - \\
\hline Anthraquinones & - \\
\hline
\end{tabular}

Table 2: Effect of Azanza garckeana on body weight of treated mice

\begin{tabular}{cccccc}
\hline Group & Baseline & Day 10 & Day 20 & Day 30 & Day 40 \\
\hline 1 & $25.37 \pm 1.13$ & $31.93 \pm 0.95$ & $34.52 \pm 0.68$ & $36.43 \pm 0.61$ & $37.75 \pm 0.56$ \\
2 & $26.50 \pm 2.42$ & $25.62 \pm 0.96$ & $27.20 \pm 2.66$ & $24.25 \pm 1.50$ & $22.83 \pm 1.16$ \\
3 & $26.93 \pm 1.53$ & $30.00 \pm 1.15$ & $30.90 \pm 0.92^{\mathrm{a}}$ & $29.16 \pm 1.20^{\mathrm{b}}$ & $28.34 \pm 0.93$ \\
4 & $28.02 \pm 1.53$ & $29.28 \pm 0.69$ & $31.08 \pm 0.74^{\mathrm{a}}$ & $32.04 \pm 0.67^{\mathrm{a}}$ & $33.30 \pm 0.54^{\mathrm{a}}$ \\
5 & $27.13 \pm 2.36$ & $29.61 \pm 1.58$ & $32.10 \pm 1.03^{\mathrm{ab}}$ & $32.61 \pm 0.82^{\mathrm{a}}$ & $33.93 \pm 1.73^{\mathrm{a}}$ \\
6 & $26.30 \pm 1.06$ & $29.13 \pm 1.15$ & $30.82 \pm 0.97^{\mathrm{ab}}$ & $32.04 \pm 0.67^{\mathrm{a}}$ & $33.30 \pm 0.54^{\mathrm{a}}$ \\
7 & $27.82 \pm 2.02$ & $31.10 \pm .07^{\mathrm{b}}$ & $32.54 \pm 1.83^{\mathrm{b}}$ & $34.48 \pm 1.62^{\mathrm{a}}$ & $35.54 \pm 1.69^{\mathrm{a}}$ \\
8 & $26.93 \pm 1.64$ & $31.81 \pm 1.10^{\mathrm{a}}$ & $33.06 \pm 1.24^{\mathrm{a}}$ & $35.61 \pm 1.74^{\mathrm{a}}$ & $35.82 \pm 1.88^{\mathrm{a}}$ \\
\hline
\end{tabular}

$\mathrm{N}=5$, values are mean \pm SEM ${ }^{\mathrm{a}}=$ Treatment duration has significant effect on weight compared to baseline value $(\mathrm{p}<0.05) . \quad{ }^{b}=$ Changes in treatment in any group also has significant effect compared to control $(\mathrm{p}<0.05)$.

1 = Control, Normal saline, $1 \mathrm{mg} / \mathrm{kg} ; 2$ = Formalin, $10 \mathrm{mg} / \mathrm{kg} ; 3$ = Formalin, $10 \mathrm{mg} / \mathrm{kg} \&$ Extract, $125 \mathrm{mg} / \mathrm{kg} ; 4=$ Formalin, $10 \mathrm{mg} / \mathrm{kg} \&$ Extract, $250 \mathrm{mg} / \mathrm{kg} ; 5$ = Formalin, $10 \mathrm{mg} / \mathrm{kg} \&$ Extract, $500 \mathrm{mg} / \mathrm{kg} ; 6$ = Extract, $125 \mathrm{mg} / \mathrm{kg} ; 7$ $=$ Extract, $250 \mathrm{mg} / \mathrm{kg} ; 8=$ Extract, $500 \mathrm{mg} / \mathrm{kg}$

Table 3: Effect of Azanza garckeana on the Testicular and Epididymis Weight of Male Mice

\begin{tabular}{lllllcl}
\hline Group & $\begin{array}{l}\text { Body Weight }(\mathrm{g}) \\
\text { Day 40 }\end{array}$ & $\begin{array}{l}\text { Weight of } \\
\text { testes }(\mathrm{g})\end{array}$ & $\begin{array}{l}\text { Testes/ } \\
\text { Body Ratio }\end{array}$ & $\begin{array}{l}\text { Length of } \\
\text { testes }(\mathrm{mm})\end{array}$ & $\begin{array}{l}\text { Epididymis } \\
\text { Weight }(\mathrm{g})\end{array}$ & $\begin{array}{l}\text { GSI } \\
(\%)\end{array}$ \\
\hline 1. & $37.75 \pm 0.56$ & $0.33 \pm 0.02$ & 0.009 & $4.47 \pm 0.09$ & $0.45 \pm 0.03$ & 0.90 \\
2. & $22.83 \pm 1.16$ & $0.35 \pm 0.03$ & 0.015 & $4.27 \pm 0.12$ & $0.74 \pm 0.08^{*}$ & $1.53^{*}$ \\
3. & $28.34 \pm 0.93$ & $0.34 \pm 0.01$ & 0.119 & $4.50 \pm 0.30$ & $0.47 \pm 0.05$ & 1.20 \\
4. & $33.55 \pm 0.95$ & $0.27 \pm 0.01$ & 0.008 & $4.20 \pm 0.35$ & $0.63 \pm 0.07^{*}$ & 0.80 \\
5. & $33.92 \pm 1.73$ & $0.29 \pm 0.03$ & 0.009 & $4.83 \pm 0.51$ & $0.68 \pm 0.03^{*}$ & 0.90 \\
6. & $33.30 \pm 0.54$ & $0.32 \pm 0.02$ & 0.0096 & $4.97 \pm 0.49$ & $0.49 \pm 0.07$ & 0.96 \\
7. & $35.54 \pm 1.69$ & $0.33 \pm 0.01$ & 0.00928 & $4.90 \pm 0.21$ & $0.50 \pm 0.02$ & 0.93 \\
8. & $35.71 \pm 1.88$ & $0.38 \pm 0.02$ & 0.0106 & $5.08 \pm 0.36$ & $0.71 \pm 0.05^{*}$ & 1.06 \\
\hline \multicolumn{6}{c}{$\mathrm{N}=5$, values are mean $\pm \mathrm{SEM} ;{ }^{*}=\mathrm{p}<0.05$ compared to control. }
\end{tabular}

1 = Control, Normal saline, $1 \mathrm{mg} / \mathrm{kg} ; 2$ = Formalin, $10 \mathrm{mg} / \mathrm{kg} ; 3$ = Formalin, $10 \mathrm{mg} / \mathrm{kg} \&$ Extract, $125 \mathrm{mg} / \mathrm{kg} ; 4=$ Formalin, $10 \mathrm{mg} / \mathrm{kg} \&$ Extract, $250 \mathrm{mg} / \mathrm{kg} ; 5$ = Formalin, $10 \mathrm{mg} / \mathrm{kg} \&$ Extract, $500 \mathrm{mg} / \mathrm{kg} ; 6$ = Extract, $125 \mathrm{mg} / \mathrm{kg} ; 7$ $=$ Extract, $250 \mathrm{mg} / \mathrm{kg} ; 8=$ Extract, $500 \mathrm{mg} / \mathrm{kg}$ 
Table 4: Effect of Formalin and Aqueous Extract of Azanza garckeana on Gonadotropins

\begin{tabular}{llll}
\hline Group & \multicolumn{1}{l}{ LH $(\mathrm{mIU} / \mathrm{ml})$} & FSH $(\mathrm{mIU} / \mathrm{ml})$ & Testosterone $(\mathrm{ng} / \mathrm{dl})$ \\
\hline 1 & $6.23 \pm 3.30$ & $14.43 \pm 3.46$ & $8.50 \pm 0.72$ \\
2 & $10.17 \pm 0.48$ & $4.50 \pm 0.49^{\mathrm{c}}$ & $4.30 \pm 1.68$ \\
3 & $14.47 \pm 7.36$ & $6.33 \pm 0.89$ & $4.90 \pm 0.43$ \\
4 & $14.76 \pm 5.11$ & $11.20 \pm 3.70$ & $4.87 \pm 0.43$ \\
5 & $13.91 \pm 4.33$ & $12.68 \pm 2.90$ & $5.17 \pm 1.28$ \\
6 & $12.90 \pm 12.35^{\mathrm{ab}}$ & $8.97 \pm 0.80$ & $6.57 \pm 0.70^{\mathrm{b}}$ \\
7 & $10.13 \pm 6.67^{\mathrm{a}}$ & $39.50 \pm 13.93^{\mathrm{ab}}$ & $7.80 \pm 0.70^{\mathrm{b}}$ \\
8 & $11.18 \pm 3.84^{\mathrm{ab}}$ & $35.13 \pm 6.52^{\mathrm{ab}}$ & $8.30 \pm 0.67^{\mathrm{b}}$ \\
\hline
\end{tabular}

$\mathrm{a}=\mathrm{p}<0.05$ compared with control (group 1). ${ }^{\mathrm{b}}=\mathrm{p}<0.05$ compared with formalin-treated (group2)

Values are expressed as Mean $\pm \mathrm{SEM} ; \mathrm{N}=5 \quad 1$ = Control, Normal saline, $1 \mathrm{mg} / \mathrm{kg} ; 2=$ Formalin, $10 \mathrm{mg} / \mathrm{kg} ; 3=$ Formalin, $10 \mathrm{mg} / \mathrm{kg} \&$ Extract, $125 \mathrm{mg} / \mathrm{kg} ; 4$ = Formalin, $10 \mathrm{mg} / \mathrm{kg} \&$ Extract, $250 \mathrm{mg} / \mathrm{kg} ; 5$ = Formalin, $10 \mathrm{mg} / \mathrm{kg}$ \& Extract, $500 \mathrm{mg} / \mathrm{kg} ; 6$ = Extract, $125 \mathrm{mg} / \mathrm{kg} ; 7$ = Extract, $250 \mathrm{mg} / \mathrm{kg} ; 8=$ Extract, $500 \mathrm{mg} / \mathrm{kg}$

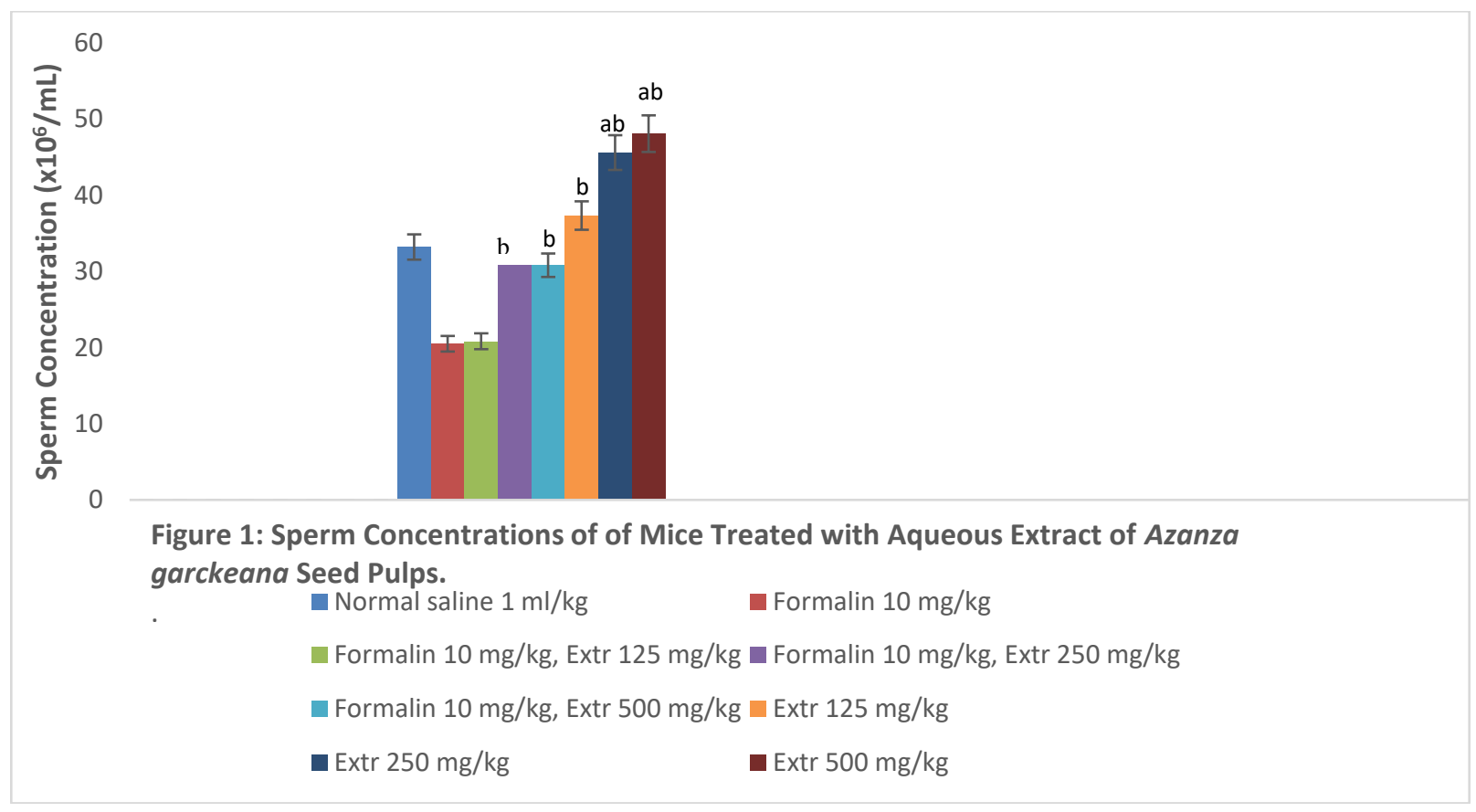

${ }^{\mathrm{a}}=\mathrm{p}<0.05$ compared with Normal saline group 1 (Control). ${ }^{\mathrm{b}}=\mathrm{p}<0.05$ compared with formalin alone group 2 Values are expressed as Mean $\pm \mathrm{SEM} ; \mathrm{N}=5$ 


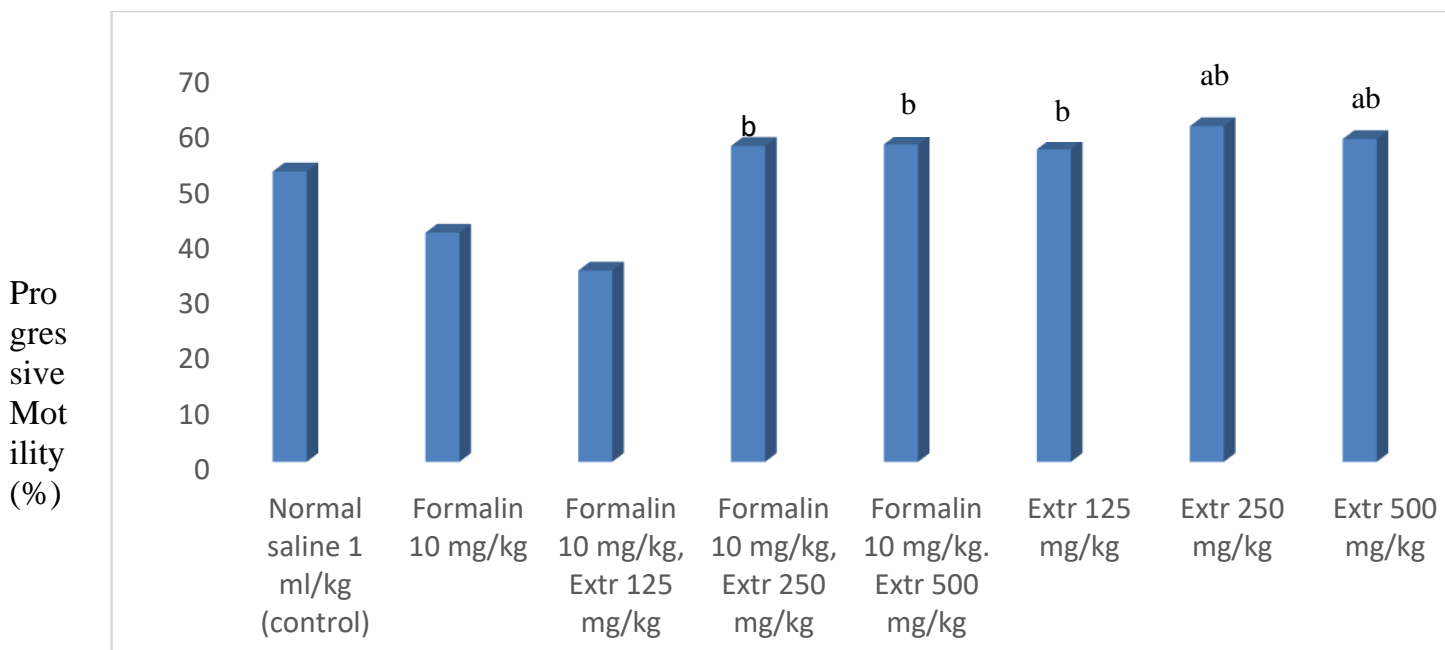

Figure 2: Progressive Motility of Sperm Cells of Mice Treated with Aqueous Extract of Azanza garckeana Seed Pulp $\quad{ }^{a}=p<0.05$ compared with Normal saline group 1 (Control). ${ }^{b}=p<0.05$ compared with formalin alone group 2 Value are expressed as Mean $\pm \mathrm{SEM} ; \mathrm{N}=5$

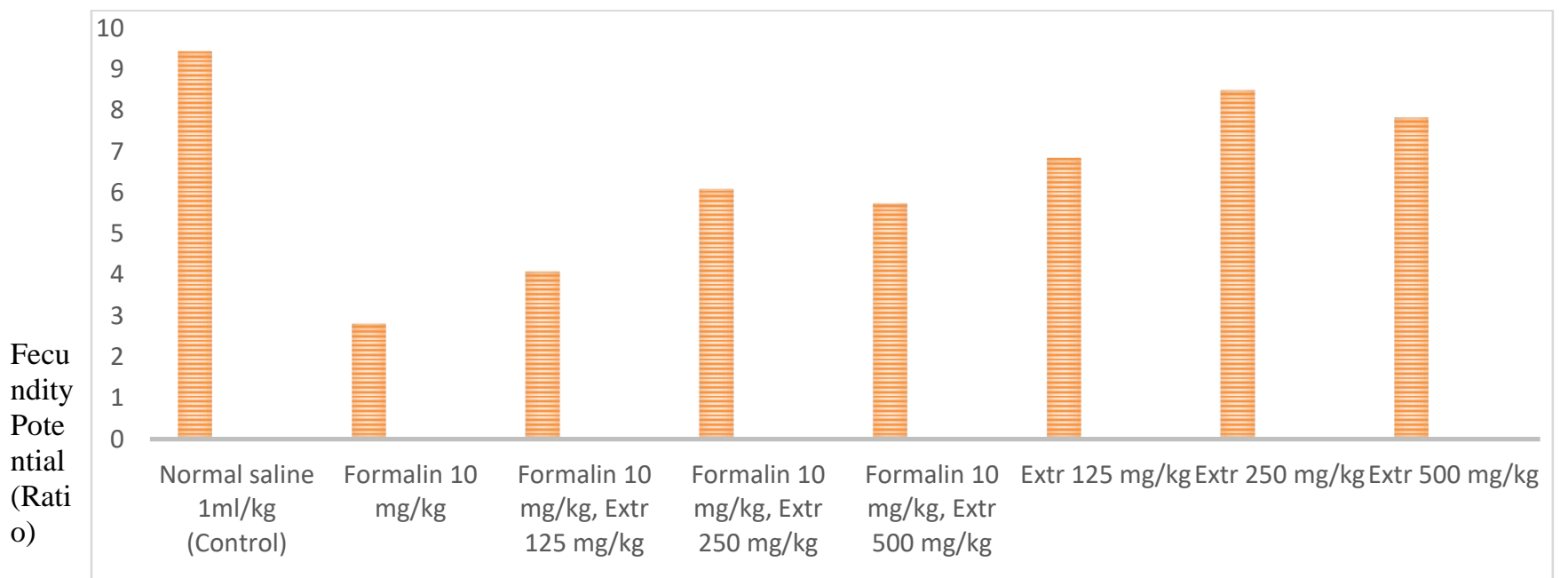

Figure 3: Fecundity Potentials of male mice Treated with Azanza garckeana

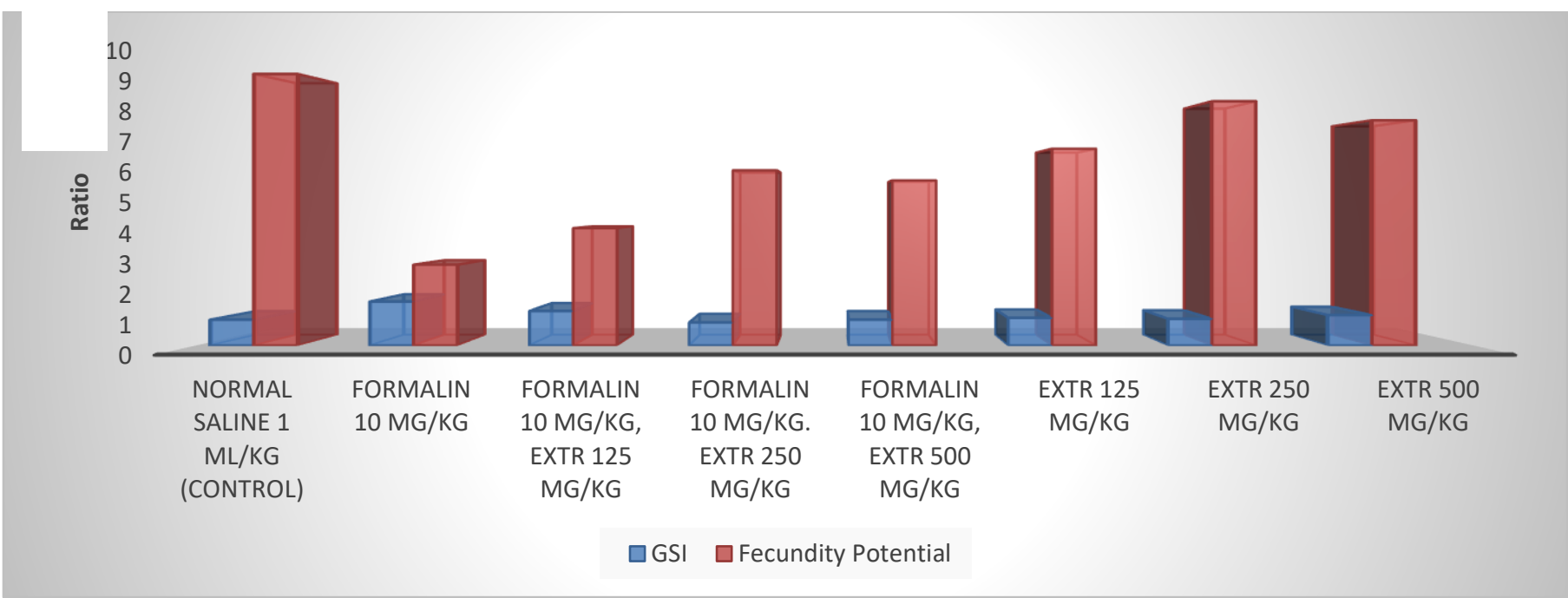


Figure 4: Gonadosomatic index (GSI) versus Fecundity Potential of male mice treated with Aqueous Extract of Azanza garckeana

\section{DISCUSSION}

Male fertility as a critical component of health issues is a multifactorial problem. Until recently infertility was generally thought of and regarded as a female problem, but as scientific research and awareness increased, it was discovered that the male gender contribute equally to the problem such that about 1 out of every 3 cases of infertility is due to the man alone [27]. Not less than 30 million men worldwide are infertile with the highest rate in Africa and Eastern Europe [28, 29]. The present study was aimed at finding a solution to such problems by exploiting our abundant medicinal plants in Africa. Some of these medicinal plants could possess phytochemicals either as single entities or in combinations that may be effective in tackling the management of infertility in man.

From the results of this study, the aqueous extract of Azanza garckeana significantly ( $\mathrm{p}<$ 0.05 ) ameliorated the decreased effect of body weight of animals induced by formalin (see Table 2). In a similar manner, the extract significantly $(\mathrm{p}<0.05)$ caused increase in body weight of treated animals. These observations correlate positively with the effect of the extract on epididymis where the extract significantly $(\mathrm{p}<0.05)$ increased its weight. However, the effect of the extract on testicular weights did not follow any regular pattern, suggesting lack of consistency of its effect on the testes. In fertility studies, the body mass is related to that of the testes by the gonadosomatic index (GSI) which is a ratio of the testicular weight and the total body mass. The GSI cut-off vary between the male and female with the male having a cut-off of 1-1.3 $\%$ while that of the female is $8 \%$ [30]. Indeed, reproductive potential has been positively correlated with male body weight [30]. Fertility has been described as the real and measurable reproductive performance of a given individual. It is a component of fecundity which is an important part of both sexual and asexual reproduction. Reproductive potential expresses maximum fecundity where it represents the capacity to reproduce and this capacity is most often related to chemical substances such as the hormones or gonadotropins [31]. On this account, the extract significantly $(\mathrm{p}<0.05)$ caused increase in gonadotropin levels at all the doses used compared to group 2 (see table 5). However, there was no significant ameliorative effect ( $p$ $>0.05$ )

The extract demonstrated a dose-dependent increase on GSI, but this was not as high as that of the group treated with formalin alone. Though, the GSI is an important index of fertility and fecundity, its validity across species of animals remains debatable. Indeed, relationship between gonadotropin and gonadal stages appears lacking and hence the use of GSI as a direct index of reproduction remains unclear, as it may be an imprecise index for gonadal stage in some species [32]. For this reason, this study assessed what we referred to as the fecundity potential in which a comparison of the amount of testosterone produce per unit of GSI was made. In this regard, the control group had the highest fecundity potential followed by animals treated with the extract alone at the dose of $250 \mathrm{mg} / \mathrm{kg}$ (see figure 3 ). The highest fecundity potential value due to the extract was observed at the dose of $250 \mathrm{mg} / \mathrm{kg}$ (see figures $3 \& 4$ ). This implies that the extract at the dose of 250 $\mathrm{mg} / \mathrm{kg}$ could be more beneficial in male infertility.

The study revealed that the extract significantly $(\mathrm{p}<0.05)$ increased the concentration of the sperm cells at the doses of 250 and $500 \mathrm{mg} / \mathrm{kg}$ either alone or in the formalin-induced toxicity group (see figure 1). In similar manner, the extract significantly ( $p$ $<0.05$ ) caused increase in rapid progressive motility $(\mathrm{p}<0.05)$. It has been reported that 
increase in sperm count and progressive sperm motility are important components of fertility. Defects in sperm motility is a high risk factor in male fertility [33]. Fecundity is actually the biologic capacity of men and women for reproduction irrespective of pregnancy, and is typically measured by end-points such as hormonal profiles and semen quality in men [28, 34].

The phytochemical analysis revealed the presence of abundant flavonoids, and these phytochemicals are reported as possessing antioxidant properties that could be beneficial in toxic conditions such as those induced by formalin [35-37]. This explains why in groups that received formalin there was marked decrease in the levels of the gonadotropins.

In conclusion, this study established the ameliorative and pro-fertility property of Azanza garckeana in male mice. This could be a novel scientific evidence that could justify its traditional ethno-medicinal use.

Acknowledgements. We wish to express our gratitude to Messrs. Solomon F Tsaku and Lungfa Ishaku of the Animal Experimental Unit, University of Jos, Jos, for their technical assistance during the daily oral administration of the extract as well as the periodical weighing of the animals. Our gratitude also goes to the Laboratory Scientist Mr. Ayuba Sendeph of the Department of Gynecology and Obstetrics, Jos University Teaching Hospital (JUTH) for offering to assist in the hormonal and sperm analysis. We remain indebted to I. $\mathrm{N}$ Tech. Nigeria (www.intech.ng.org), Murtala Mohammed Way, Jos, for typing the manuscript and some statistical analysis.

\section{REFERENCES}

1 Orwa C, Mutua A, Kindt R, Jamnadass R, Anthony S. (2009). Agro forest tree Database: a tree reference and selection guide version 4.0 http://www.worldagroforestry.org/sites/treedbs/treeda tabases.asp

2 Mutindi MV (2014). Phytochemical investigation of Harrisonia abyssinica and Thespesia garckeana for antiplasmodial and antimicrobial compounds. M.Sc. Thesis, University of Nairobi, Nairobi.

3 Masila VM, Midiwo, JO, Zhang J, Gisacho BM, Munayi R. Anti-vancomycin-resistant Enterococcus faecium and E. faecalis activities of(-)-gossypol and derivatives from Thespesia garckeana. Natural Product Communication 2015; 10: 613-616.

4 Dikko YJ, Khan ME, Tor-Anyiim TA, Anyam JV, Linus UA. In vitro antimalarial activity of Azanza garckeana and isolation of one of its active principles, Betulinic acid. British Journal of Pharmaceutical Research 2016; 14(1): 1-10, doi: 10.9734/BJPR/2016/30152

5 Maroyi A. Azanza garckeana fruit tree: phytochemistry, pharmacology, nutritional and primary healthcare applications as herbal medicine: A Review. Research Journal of Medicinal Plants 2017; 11: 115-123, doi: 10.3923/rjmp.2017.115.123

6 Amuri BM, Maseho L, Simbi P, Okusa P, Duez, Byanga K. Hypoglycemic and antihyperglycemic activities of nine medicinal herbs used as antidiabetic in the region of Lubumbashi (DR Congo).

Phytotherapy Research. 2017; 31: 1029-1033.

7 Mshelia EH, Watirahyel EM, Maigari AU, Yohanna $\mathrm{C}$, Ismail $\mathrm{F}$. Cytotoxicity and antioxidant activity of stem bark extracts of Azanza garckeana (kola of Tula). European Journal of Pure and Applied Chemistry 2016; 3: 16-24.

8 Connelly MPE., Fabiano IH., Patel SM, Kinyanjui EK, Mberu, Watkins WM. Antimalarial activity in crude extracts of Malawian medicinal plants. Annals of Tropical Medicine. Parasitology 1996; 90: 597-602

9 Saka JDK, Msousthi JD. Nutritional value of edible fruits of indigenous wild trees in Malawi. Forest Ecology and Management 1994; 64; 245-248.

10 Nkafamiya II, Ardo BP, Osemeahon SA, Akinterinwa A. Evaluation of nutritional, nonnutritional, elemental content and amino acid profile of Azanza garckeana (Goron Tula). Br. J. Applied Sci. Technol. 2015; 12: 1-10.

11 Zhang YJ, Gan RY, Li S, Zhou Y, Li AN, Xu, DP, $\mathrm{Li} \mathrm{HB}$. Antioxidant phytochemicals for the prevention and treatment of chronic diseases. Molecules 2015; 20: $21138-21156$.

12 Joel JM, Barminas JT, Riki EY, Yelwa JM, Edeh F (2018). Extraction and characterization of hydrocolloid pectin from Goron Tula (Azanza garckeana) fruits. World Scientific News 101 (2018), pp 157-171 
13 Ochokwu IJ, Ajijola KO, Onyia LU. Effect of Azanza garckeana (Goron Tula) pulp meal inclusion on growth performance of Clarias gariepinus Broodstock (Burchell, 1822). Journal of Tropical Agriculture 2014; 14: 134-146

14 Onyia LU, Ochokwu IJ, Diyaware MY, Michael KG. Effect of Azanza garckeana on egg quality of African catfish (Clarias gariepinus). International Journal of Fisheries and Aquatic Sciences 2015; 4(2): 35-39

15 Hawkes S, Hart G. Men's sexual health matters: promoting reproductive health in an international context. Tropical Medicine and International Health 2000; 5(7): A37-A44

16 European Science Foundation (ESF) (2010). Male Reproductive Health, a science policy briefing, September 2010, www.esf.org

17 National Institute of Health (NIH) (2011).Guide for care and use of laboratory animals, $8^{\text {th }}$ Edition, The National Academic Press, Washington DC, USA.

18 Adegboye MF, Akinpelu DA, Okoh A. The bioactive and phytochemical properties of Garcinia kola seed extract on some pathogens. African. Journal of Biotechnology 2008; 7(21): 3934-3938

19 Trease G, Evans WC. Pharmacognosy, Baillere Tindall, London, $12^{\text {th }}$ Edition, 1983, pp 387, 475-476

20 Otsuka H (2006). Purification by solvent extraction using partition coefficient. In: SD Sarker, Z Lafif and GI Alexander (Eds). Methods in Biotechnology: Natural Product Isolation, $2^{\text {nd }}$ Ed, Human Press Inc, Totowa, New Jersey, USA.

21 Wall ME, Eddy CR, McClemann ML. Detection and estimation of steroid-saponin in plant tissues. Liebigs Annalen de Chemie 1952; 23: 1337-1338

22 Sofowora A. Medicinal plants and traditional medicine in Africa. John Wiley and Sons, New York, in association with Spectrum Books Ltd, Ibadan, Nigeria 1982, pp 142-145

23 Odebedy O, Sofowora A. Phytochemical screening of Nigerian medicinal plants. Lloydia 1978; 41: 41234.

24 Braide VP, Agube GE, Udoh FV. Effect of Garcinia kola seed alkaloid extract on levels of gonadal and pituitary gonadotropins in rat serum. Nigerian Journal of Physiological Sciences 2003; 18(1-2): 59-64

25 Gan SD, Patel KR. Enzyme immunoassay (EIA) and enzyme-linked immunosorbent assay (ELISA). Journal of Investigative Dermatology 2013; 133: e12
26 Bavister B, Andrew JC. A rapid sperm motility bioassay procedure for quality control testing of water and culture media. Journal of In-vitro fertilization and embryo transfer 1988; 5: 67-75

27 Ikechebelu JJ, Adinma JI, Orie EF, Ikegwuonu SO. High prevalence of infertility in S.E. Nigerian Journal of Obstetrics and Gyneacology 2003; 23(6): 657-659

28 Buck Louis GM. Fecundity and Fertility. In: Buck Louis GM, Platt RW (eds). Reproductive and perinatal epidemiology. New York. Oxford University Press, 2011, pp 16-61

29 Agarwal A, Mulgund A, Hamada A, Chyatte MR. A unique view on male infertility around the globe. Reproductive Biology and Endocrinology 2015; 13: $37-46$

30 Zeyi JN, Love OP, Hoggs DM. Evaluating gonadosomatic index as an estimate of reproductive condition in the invasive round goby, Neogobicus melanostomus. Journal of Great Lake Research 2013; doi: 10.1016/j.jglr.2013.12.004.

31 Smith-Gill SJ, Berven RA. In vitro fertilization and assessment of male reproductive potential using mammalian gonadotropin-releasing hormones to induce spermiation in Rana sylvatica. Copeia 1980; 1980(4): 723-728, doi: 10.2307/1444450.

32 Packard GC, Boardman TJ. The misuse of ratios, indices and percentages in echo-physiological research. Physiological Zoology 1988; 61: 1-9

33 McLaren JF. Infertility evaluation. Obstetrics and Gynecology Clinics of North America 2012; 39(4): 453-463.

34 Buck-Louis GM. Male fecundity and its implications for health and diseases across the lifespan. Human Reproduction 2014; 29 (7): 1351-1352, doi: 10.1093/humrep/deu108

35 Jamalan M, Ghafari MA, Hosseinzadeh P, Hashemitabar M, Zeinali M. Human sperm quality and metal toxicants: protective effects of some flavonoids on male reproductive functions. International Journal of Fertility and Sterility 2015; 93(3): 215-222

36 Neiderberger C. Re: The role of sperm oxidative stress in male infertility and the significance of oral antioxidant therapy. Reproductive Toxicology 2012; 34(3): 298-307

37 Lora LV, Pasqualotto EB, Borger Jr E, Braga DPAF, Salvador M, Pasqualotto EF. Flavonoids may increase semen quality in infertile men with oligospermia. Fertility and Sterility 2008; 90 (Suppl): S190-S191 